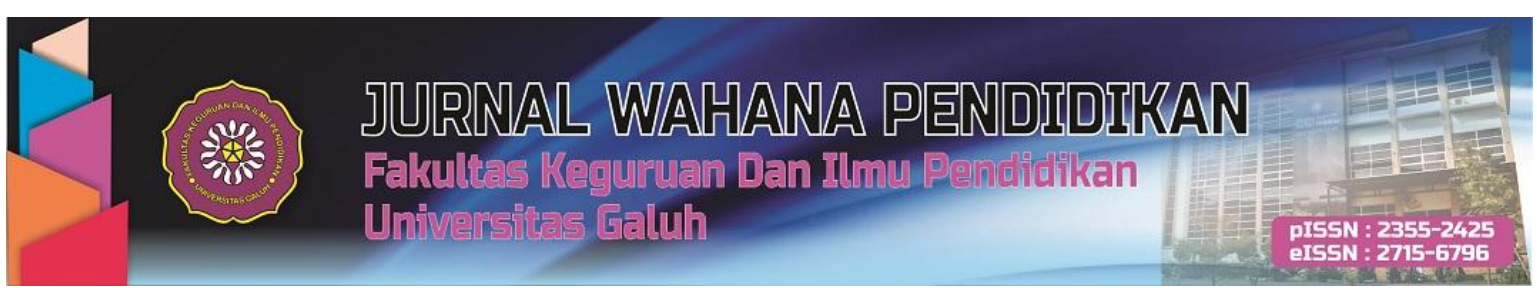

https://jurnal.unigal.ac.id/index.php/jwp

\title{
PENGEMBANGAN MODEL PEMBELAJARAN IPS BERSASIS BUKU CERITA MASYARAKAT ADAT KAMPUNG KUTA DALAM PENGELOLAAN SUMBER DAYA ALAM UNTUK MEMBENTUK KARAKTER SISWA SD DI KABUPATEN CIAMIS
}

\author{
Wulan Sondarika ${ }^{1}$, Muhammad Bachrul Ulum ${ }^{2}$, Enok Yuniar ${ }^{3}$, Risna Andriyani 4 \\ 1,2,3,4 Universitas Galuh, Jl. R. E. Martadinata No.150, Ciamis, Indonesia \\ Email: wulansondarika13@gmail.com
}

\begin{abstract}
The purpose of this study is to determine the effectiveness of IPS-based learning media based on the storybook of the Kampung Kuta Indigenous Peoples in the management of natural resources to shape the character of elementary school students in Ciamis, Indonesia. This study was conducted using the Research and Development (R \& D) method where the method emphasizes the final product produced of the study. The steps of the R \& $D$ research method are (a) potential and problems, (b) data collection, (c) product design, (d) design validation (e) use of the design (f) trial use, (g) product revisions, (h) trial use, (i) product revision, (j) mass product manufacturing. The results showed that the storybook of the Indigenous People of Kampung Kuta was able to provide a new model in terms of developing social studies learning media. Thus, the students have insight, positive character, and concern for their surrounding environment.
\end{abstract}

Keywords: Storybook Based Learning Model, Kampung Kuta Indigenous Community, Management of Natural Resources, Forming Character

\begin{abstract}
ABSTRAK
Tujuan penelitian ini adalah untuk mengetahui efektifitas media pembelajaran berbasis IPS berbasis buku cerita Masyarakat Adat Kampung Kuta dalam pengelolaan sumber daya alam untuk membentuk karakter siswa SD di Kabupaten Ciamis. Penelitian ini dilakukan dengan menggunakan metode R\&D Reasearch and Development dimana metode ini menekankan pada produk akhir yang dihasilkan dari penelitian. Adapun langkah-langkah metode penelitian R\&D adalah (a) potensi dan masalah, (b) pengumpulan data, (c) desain produk, (d) validasi desain (e) pemakaian desain (f) uji coba pemakaian, (g) revisi produk, (h) uji coba pemakaian, (i) revisi produk, (j) pembuatan produk masal. Hasil penelitian menunjukkan bahwa dengan buku cerita Mayarakat Adat Kampung Kuta mampu memberikan warna baru dalam hal pengembangan media pembelajaran IPS sehingga siswa memiliki wawasan, karakter positif, dan kepedulian terhadap lingkungan sekitar.
\end{abstract}

Kata Kunci: Model Pembelajaran Bersasis Buku Cerita, Masyarakat Adat Kampung Kuta, Pengelolaan Sumber Daya Alam, Membentuk Karakter

Cara sitasi:

Sondarika, W., Ulum, M. B., Yuniar, E., \& Andriyani, R. (2020). Pengembangan Model Pembelajaran Ips Bersasis Buku Cerita Masyarakat Adat Kampung Kuta Dalam Pengelolaan Sumber Daya Alam Untuk Membentuk Karakter Siswa Sd Di Kabupaten Ciamis. Jurnal Wahana Pendidikan, 7(1), 45-52. 


\section{PENDAHULUAN}

Pendidikan merupakan hal yang sangat penting untuk pembentukan generasi mendatang, tentunya dengan semangat membangun sumberdaya manusia yang baik dan juga agar berguna bagi Nusa, Bangsa dan Negara. Maka dengan adanya semangat ini menuntut perbaikan mutu pendidikan tingkat dasar, hal ini sangat perlu di lakukan agar terciptanya peserta didik yang berkarakter.

Pendidikan tidak bisa berdiri sendiri, tetapi memerlukan contoh konkrit agar anak didik mudah memahami pelajaran yang di ajarkan. Untuk itu pendidik harus berinovasi dalam melaksanakan kegiatan belajar pembelajaran.

UU Guru dan Dosen BAB II Pasal 6, tahun 2005 menyebutkan: "tujuan pendidikan nasional, yaitu berkembangnya potensi peserta didik agar menjadi manusia yang beriman dan bertaqwa kepada Tuhan Yang Maha Esa, berakhlak mulia, sehat, berilmu, cakap, kreatif, mandiri, dan menjadi warga negara yang demokratis serta bertanggung jawab" (Himpunan perundang-undangan RI Tentang Guru dan Dosen, 2006:20).

Mewujudkan cita-cita tersebut kita sebagai pendidik bisa mengajak peserta didik mengenal salah satu kebudayaan di Indonesia yang berhasil mengelola sumberdaya alam sehinga bisa terjaga dengan baik, yaitu di Kampung Adat Kuta. Di Kampung ini, kita bisa mengajak peserta didik untuk memahami bahwa alam itu harus di jaga agar peserta didik bisa meniru untuk menjaga kelangsungan alam di daerahnya masing-masing, dan kita mencoba untuk mengulas kehidupan masyarakat Kampung Adat Kuta dengan media buku cerita untuk anak sekolah dasar berdasarkan perilaku masyarakat Adat Kampung Kuta yang dapat menjaga alam sekitamya dengan baik.

Melihat dari tujuan pembelajaran IPS, pada dasarnya permasalahan lingkungan menjadi bagian dari pembelajaran IPS. Banyak diantaranya yang tidak mengerti mengenai kerusakan alam atau permasalahan lingkungan. Permasalahannya seperti banjir, kebakaran hutan longsor, sampah yang menggundung, lingkungan yang kotor yang dapat menyebabkan wabah penyakit bagi manusia terkadang hanya dianggap sesuatu yang wajar.

Sebuah usaha untuk menumbuhkan sikap dan perilaku yang mendukung terhadap lingkungan membutuhkan suatu pendidikan yang berkaitan. Pembelajaran sejarah berbasis ecopedagogy yang terkemas dalam mata pelajaaran IPS bertujuan untuk menyiapkan peserta didik memiliki kompetensi atau kecerdasan ekologis. Kecerdasan yang dimaksud yaitu berupa pemahaman tentang pembangunan berkelanjutan, pemahaman tentang semakin terbatasnya sumber daya alam, kemampuan beradaptasi atau hidup selaras dengan lingkungan yang menjunjung tinggi keadilan demi menyiapkan generasi yang akan datang yang akan dihadapkan pada persoalan-persoalan ekologis.

Kampung Adat Kuta yang terletak di Desa Karangpaninggal, Kecamatan Tambaksari, Kabupaten Ciamis, Jawa Barat terkenal sangat menghormati budaya leluhurnya, salah satunya yaitu budaya pamali atau tabu yang berfungsi sebagai pengendali segala aktifitas manusia disana. Adat dan tradisi menjadi satu peninggalan leluhur yang tidak boleh di langgar. Kampung ini dikatagorikan sebagai Kampung Adat karena mempunyai kesamaan dalam bentuk dan bahan fisik bangunan rumah, adanya ketua adat dan adanya adat istiadat yang mengikat masyarakatnya (Aulia, 2010). Seperti halnya kampung-kampung adat yang mempunyai hukum tersendiri, Kampung Adat Kuta juga memiliki hukum adat tersendiri dalam pengelolaan sumberdaya alam dengan tujuan menciptakan kelestarian bagi lingkungan.

Hutan yang hendak kita jadikan acuan dalam pembelajaran kepada peserta didik tentang menjaga alam yaitu mengenai hutan Leuweung Gede di Kampung Adat Kuta. Leuweung Gede merupakan hutan larangan yang sangat di tabukan oleh masyarakat disana karena mereka memperlakukan hutan tersebut sebagai sesuatu yang suci dan harus di jaga. Disini kita bisa mendapatkan pelajaran mengenai prilaku hijau, yaitu bagaimana penduduk disana menjaga alam sekitar dengan baik sehingga dapat menghindari bencana yang tidak di inginkan.

Berdasarkan pemaparan dari latar belakang diatas permasalahan dari penelitian ini dijabarkan dalam pertanyataan-pertanyaan sebagai berikut:

1. Bagaimana proses pembelajaran IPS pada siswa SD di Kabupaten Ciamis? 
2. Bagaimana proses pengembangan model pembelajaran IPS berbasis buku cerita Masyarakat Adat Kampung Kuta dalam pengelolaan sumber daya alam?

3. Bagaimana efektifitas model pembelajaran IPS berbasis buku cerita Masyarakat Adat Kampung Kuta dalam pengelolaan sumber daya alam untuk membentuk karakter siswa SD di Kabupaten Ciamis ?

Tujuan dari penelitian ini tidak lain untuk mengembangkan sarta mengukur keefektifitasan media pembelajaran IPS berbasis buku cerita Masyarakat Adat Kampung Kuta dalam pengelolaan sumber daya alam untuk membentuk karakter siswa SD di Kabupaten Ciamis.

Penelitian tentang pengembangan model pembelajaran IPS bersasis buku cerita ini penting dilakukan sebabnya belum ditemukan buku cerita untuk anak SD yang bertemakan perilaku masyarakat adat Kampung Kuta dalam pengelolaan sumber daya alam dengan metode pamalinyal tabu. Beberapa penelitian hanya mengkaji tentang pentingnya pengeloaan sumber daya alam saja, berbeda dengan penelitian ini bukan hanya menganalisis perilaku masyarakat adat kampung kuta saja melainkan di aplikasikan pada sebuah buku cerita untuk bahan ajar peserta didik pada tingkat SD supaya dapat membentuk karakter cinta lingkungan dari usia dini. Dengan demikian sudah jelas bahwa penelitian ini terdapat perbedaan dengan penelitian terdahulu.

Untuk melihat adanya perbedaan antara penelitian ini dengan penelitian terdahulu yang terkait dengan pengelolaan sumber daya alam oleh masyarakat adat antara lain yang pertama Tia Oktaviani dkk, 2010 menjelaskan bahwa kelestarian sumberdaya alam di Kampung Kuta wujud dari pentingnya lingkungan yang harus dijaga salah satunya kearifan lokal yang sudah dikenal dan merupakan amanah yang dilakukan turun-temurun sejak ratusan tahun lalu, namun tidak dihubungkan dengan pembelajaran.

Selanjutnya yaitu penelitian Sondarika (2019) dalam prosiding seminar Nasional yang hampir sama dengan penelitian ini yang dikaitkan dengan pembelajaran namun tidak berbentuk produk bahan ajar. Berdasarkan hasil penelitian yang dilakukan oleh Wulan bahwa Kampung Kuta memiliki hutan keramat yang diberi nama oleh leluhurnya yaitu Leuweung Gede sebagai simbol keberlangsungan kebudayaan yang masih tetap dijaga dan dipelihara sebagai warisan nenek moyang.

Penelitian lain yang terkait dengan pengeloaan sumber daya alam yaitu oleh Hidayat (2011) menurut penelitian yang dilakukan oleh Hidayat bahwasannya kelembagaan lokal dalam pengelolaan sumberdaya alam yang dilakukan menjadi praktek kehidupan pada komunitas adat-

Selanjutnya Suparmini dkk, (2013) dalam penelitiannya mengungkapkan bahwa kehidupan masyarakat Baduy masih kental mewarnai adat, budaya, dan tradisi. Utama yang mewarnai masyarakat Baduy, yaitu sikap hidup sederhana, bersahabat dengan alam yang alami, dan spirit kemandirian.

Menurut penelitian yang dilakukan oleh Sahlan (2012) bahwa masyarakat adat Wana hubungan dengan lingkungan menjadi sesuatu yang sangat penting yang dibina sejak awal kehidupannya, bahkan sejak awal masyarakatnya. Salah satu wujud kearifan lokal yang diterapkan oleh masyarakat Wana adalah dalam praktik penggunaan produk hutan sebagai salah satu sumber penghidupan dan upaya mereka untuk melestarikannya melalui tingkah laku sosial berbasis adat.

\section{METODE PENELITIAN}

Penelitian ini menggunakan metode Reasearch and Development dimana metode ini menekankan pada produk akhir yang dihasilkan dari penelitian. Penelitian dan pengembangan merupakan metode penghubung atau pemutus kesenjangan antara penelitian dasar dengan penelitian terapan. Sering dihadapi adanya kesenjangan antara hasil-hasil penelitian dasar yang bersifat teoritis dengan penelitian terapan yang bersifat praktis. Penelitian dan Pengembangan adalah suatu proses atau langkahlangkah untuk mengembangkan suatu produk baru atau menyempurnakan produk yang telah ada. Yang dimaksud dengan produk dalam konteks ini adalah tidak selalu berbentuk hardware (buku, modul, alat bantu pembelajaran di kelas dan laboratorium), tetapi bisa juga perangkat lunak (software) seperti program untuk pengolahan data, pembelajaran di kelas, perpustakaan atau laboratorium, ataupun model-model pendidikan, pembelajaran pelatihan, bimbingan, evaluasi, manajemen, dan lain-lain. Adapun langkahlangkah metode penelitian R\&D adalah (a) potensi dan masalah, (b) pengumpulan data, (c) desain 
produk, (d) validasi desain (e) pemakaian desain (f) uji coba pemakaian, (g) revisi produk, (h) uji coba pemakaian, (i) revisi produk, (j) pembuatan produk masal (Sugiyono, 2012).

Menurut Sugiyono (2009) dalam pelaksanaan $R$ \& D, ada beberapa metode yang digunakan yaitu metode deskriptif, evaluative dan eksperimental.Metode penelitian deskriptif digunakan dalam penelitian awal untuk menghimpun data tentang kondisi yang ada. Metode penelitian awal untuk mengevaluasi proses uji coba pengembangan suatu produk. Dan metode eksperimen digunakan untuk menguji.Menguji keampuhan dari produk yang dihasilakan.

\section{HASIL DAN PEMBAHASAN}

\section{Proses Pembelajaran IPS di SD Kabupaten Ciamis Model Pembelajaran IPS di SD Model Aulady}

SD Model Aulady merupakan SDIT swasta. Peneliti melakukan wawancara di SD Model Auady kepada kepala sekolah, guru serta siswa. Hasil dari observasi pertama yaitu kepala sekolah menjelaskan mengenai perangkat pembelajaran sudah hampir memenuhi criteria diantaranya terdapat alat bantu untuk kegiatan olahraga seperti lapangan, kolam renang, raket, bola dan sebaginya. Sedangkan untuk mata pelajaran lain seperti Matematika dan IPA juga sudah memiliki alat bantu untuk melakukan pembelajaran. Untuk mata pelajaran IPS atau sosial, sekolah sudah memiliki alat bantu diantaranya adalah peta dunia, peta Indonesia Globe, alat peraga IPS (KIT Gejala Alam), dan perpustakaan terdapat buku pelajaran serta buku cerita. Selanjutnya kepala sekolah menjelaskan, hal ini tinggal kekreativitasan guru saja dalam mengemas pembelajaran di kelas. Selanjutnya hasil wawancara dari guru juga sama, tidak jauh beda dengan yang dijelaskan oleh kepala sekolah, bahwa untuk alat bantu sudah hampir memadai. Bahkan untuk perpustakaan juga sudah ada dan sering digunakan oleh siswa untuk membaca apabila sedang jam istirahat atau dipergunakan dalam pembelajaran. Observasi selanjutnya peneliti melakukan wawancara dengan 10 siswa. Siswa disana menjelaskan guru sudah cukup kreativ dalam melakukan pembelajaran, apalagi untuk mata pelajaran olahraga, matematika dan IPA. Tetapi untuk mata pelajaran IPS dirasa kurang kreatif dikarenakan alat bantu yang kurang memadai dan guru hanya menggunakan buku paket yang sudah tersedia.

\section{Model Pembelajaran IPS di SDN 1 Saguling}

Fasilitas untuk pendukung pembelajaran di SDN 1 Saguling hampir sama dengan yang ada di SD Model Aulady, namun yang membedakannya tidak ada fasilitas kolam renang untuk mata pelajaran olahraga. Peneliti melakukan wawancara kepada kepala sekolah, guru dan siswa. Menurut kepala SDN 1 Saguling membenarkan bahwa media pembelajaran yang ada di sekolah dasar tempat beliau mengajar masih sangat terbatas, hanya ada sebuah globe, papan tulis (blackboard) dan papan flanel yang ada di tiap-tiap kelas, peta, alat peraga organ tubuh manusia, radio/tape, bola voli, bola basket, bola sepak, bola kasti, pemukul kasti, dan net voli. Namun, setelah adanya bantuan dana dari pemerintah, pihak sekolah yang bekerjasama dengan wali murid dan masyarakat sekitar memanfaatkan dana dari pemerintah tersebut untuk melakukan pembangunan yang berkala, pengadaan sarana dan prasarana lebih lanjut, terutama dalam pengadaan media pembelajaran sebagai pendukung atau alat bantu dalam proses belajar mengajar di sekolah. Saat ini, media-media pembelajaran yang ada di SDN 1 Saguling antara lain, radio/tape, sebuah laptop, LCD Proyektor, dua buah Globe, Papan Tulis (Blackboard dan Whiteboard), Papan Flanel, alat peraga IPS (KIT Gejala Alam), alat peraga "KIT Tata Surya", alat-alat olahraga, Peta Indonesia, serta berbagai gambar-gambar dinding yang dapat difungsikan sebagai media pembelajaran siswa di kelas dan perpustakaan yang isi beberapa buku pelajaran serta buku cerita. Menurut guru maple disana mengatakan bahwa memang dalam setiap pembelajaran pihknya tidak pernah mengunakan buku cerita hanya menguakan buku paket IPS yang tersedia saja. Dan hal ini dibenarkan oleh beberapa siswa di wawancari oleh peneliti bahwa guru IPS di SDN 1 Saguling hanya menggunakan buku atau peta dalam pembelajaran IPS, tidak pernah menggunakan inovasi baru dalam pembelajaran di kelas. 


\section{Hasil Observasi Untuk Dasar Pengembangan Media Pembelajaran Hasil Observasi}

a. (Kurikulum). Secara umum kurikulum yang dipakai di Sekolah Dasar Ciamis yang menjadi objek peneliti masih menggunakan copy paste dari BNSP (Badan Standar Nasional Pendidikan ) sehingga tidak ada pengembangan sama sekali.

b. (RPP). Berdasarkan hasil penelitian bahwa belum semua guru dalam melakukan tugas mengajar malakukan persiapan secara maksimal terutama dalam penulisan RPP, sebagian besar guru masih menggunakan RPP cetakan

c. (Proses Pembelajaran). Aktivitas pembelajaran kurang variatif metode yang digunakan rata-rata metode ceramah, diskusi ada kecenderungan bahwa pelajaran IPS adalah pelajaran hafalan. pemahaman seperti ini berakibat pada pembelajaran yang lebih menekankan pada verbalisme.

d. (Sarana pembelajaran). Sarana pembelajaran sangat penting untuk mencapai tujuan pembelajaran IPS. Pada umumnya sarana untuk mendukung pembelajaran IPS masih sangat minim.

e. (Pemahaman siswa). Pemahaman siswa di sekolah tidak mengetahui tentang leuweung gede.

\section{Deskripsi Hasil Studi lapangan yang Berkaitan Dengan Leuweung Gede}

Kampung Kuta adalah desa adat yang terletak di desa Karangpaninggal Kecamatan Tambaksari Kabupaten Ciamis. Kampung Kuta merupakan merupakan salah satu komunitas masyarakat adat yang termasuk dalam Aliansi Masyarakat Adat Nusantara (AMAN) dari tahun 2002. Masyarakat Kampung Kuta sampai saat ini masih memegang teguh adat istiadat para leluhurnya (karuhun) dan dapat menyatu dengan alam.

Di Kampung Adat Kuta terdapat hutan larangan yang sangat di tabukan oleh masyarakatnya. Leuweung Gede ini bagi masyarakat Kampung Kuta bukan sekedar hutan biasa, hutan ini dikeramatkan dengan kata pamali seperti adanya larangan mengambil ranting apalagi menebang pohon di hutan tersebut, ini menjadikan hutan tetap terjaga kelestariannya, karena dengan adanya larangan tersebut dapat membuat masyarakat sekitar enggan untuk merusak Leuweung Gede. Apabila melanggar maka akan mendatangankan malapetaka pada dirinya. Dengan demikian hutan lindung Leuweung Gede terhindar dari pembabakan dan penjarahan, ini merupakan nilai kelestarian yang ada pada hutan lindung Situ Lengkong. Hutan Lindung Leuweung Gede memiliki luas 40 ha dan hutan tersebut masih tetap terjaga keasriannya. Leuweung Gede merupakan hutan milik Negara dan diakui oleh masyarakat Kampung Kuta dan dijadikan hutan adat.

\section{Pengembangan Model Pembelajaran Berbasis Buku Cerita Masyarakat Adat Kampung Kuta dalam Pembelajaran IPS di Kabupaten Ciamis}

Dalam proses pengembangan penelitian ini, tentunya spesifikasi yang dihasilkan adalah model pembelajaran berbasis buku cerita masyarakat adat Kampung Kuta dalam pengelolaan sumber daya alam. Hal ini disesuaikan dengan materi pada SD kelas IV yaitu Mengenal Sumber Daya Alam. KD: Mengenal aktifitas ekonomi yang berkaitan dengan sumber daya alam dan potensi lain di daerahnya.

Davis (1997:1) Pernyataan tersebut bermakna bahwa alasan cerita bergambar dijadikan sebagai alat pendidikan yang menarik adalah: (a) mendorong semangat belajar; (b) mudah didapatkan di koran dan toko buku; (c) berisi cerita tentang kehidupan sehari-hari; dan (d) memberikan gaya belajar yang bervariasi.

Kerangka teoritis dalam pengembangan model pembelajaran berbasis buku cerita Masyarakat Adat Kampung Kuta ini ialah proses pembelajaran IPS yang mengacu pada filosofi konstruktivisme. Dimana siswa akan mendapatkan pengetahuan tentang pentingnya menjaga kelestarian alam melalui pengalaman sendiri melalui membaca, menelusuri makna gambar, menghayati gambar yang ada di dalam buku cerita, serta bereksperimen sendiri. Maka dalam pandangan konstruktivisme ini peserta didik diharapkan memiliki kemampuan berfikir dan memahami untuk mengembangkan pengetahuan mereka dari hasil membaca buku cerita lalu mengaplikasikan pengetahuan yang mereka pahami dalam kehidupan sehari-hari 
Tahapan yang harus dilakukan oleh siswa dan guru dalam penerapan model pembelajaran sejarah berbasis buku cerita, yang memadukan beberapa metode dan pendekatan. Tahap Pendahuluan, Guru memberikan apersepsi terkait dengan SK, KD dan Materi Pokok yang akan pada pertemuan tersebut, sambil menyampaikan beberapa informasi stimulus serta pertanyaan awal mengenai materi yang akan disampaikan. Dilanjutkan dengan pembagian kelompok (satu kelompok 4-5 siswa secara heterogen, disesuaikan dengan jumlah siswa dalam kelas. Kegiatan inti, berupa siswa membaca buku cerita tentang pengelolaan sumber daya alam yang dilakukan masyarakat adat kampung kuta sebagai sajian materi pelajaran. Model pembelajaran berbasis buku cerita ini dapat dilanjutkan dengan pemberian tugas kepada kelompok yang sudah dibentuk. Langkah selanjutnya guru memberikan kuis atau pertanyaan. Model pembelajaran berbasis buku cerita ini dapat dapat dipadukan dengan beberapa metode pembelajaran kooperatif lain seperti Discovery. Adapun draf yang akan dikembangkan oleh penulis diantaranya; 1) RPP, 2). bahan ajar berupa buku cerita tentang Masyarakat Adat Kampung Kuta dalam pengelolaan sumber daya alam. Hal ini sudah di padukan dengan materi yang ada di sekolah pada kelas IV SD.

\section{Penilaian oleh Ahli Model, Desain dan Ahli Materi}

Untuk mengevaluasi model pembelajaran yang telah diproduksi maka dilakukan validasi oleh ahli materi dan model pembelajaran. Dalam penelitian ini sebagai validatornya adalah (1). Nugraha Wirasudarma, BscF sebagai ahli model dan desain pembelajaran, (2). Aay, S.Pdi Kepala Sekolah, (3). uji coba lapangan pada satu kelas yakni 18 siswa.

Tabel. 1

Hasil Validasi Ahli Materi

Validasi oleh Nugraha Wirasudarma, BscF

\begin{tabular}{llccc}
\hline \multicolumn{1}{c}{ Aspek Penilaian } & 1 & Skor & \\
No & 2 & 3 & 4 & 5 \\
\hline $1 . \quad \begin{array}{l}\text { Kesesuaian isi materi dengan } \\
\text { tujuan pembelajaran }\end{array}$ & & & $\checkmark$ & \\
2. $\quad \begin{array}{l}\text { Kesesuaian isi materi dengan } \\
\text { tingkat pendidikan }\end{array}$ & & & $\checkmark$ \\
Kesesuaian cerita dengan silabus & & & \\
$\quad \begin{array}{l}\text { pembelajaran } \\
\text { Jumlah }\end{array}$ & & 2 & 1 \\
Jumlah $x$ Skor & & $2 \times 4$ & $1 \times 5$ \\
Jumlah Total & 13 & & \\
Rerata \\
Keterangan
\end{tabular}

Hasil validasi dari ahli materi model pembelajaran ini mempunyai jumlah total nilai 4,3 dan secara keseluruhan dinyatakan Baik dan layak diterapakan dalam proses pembelajaran.

Analisis data oleh ahli materi adalah bertujuan untuk mengetahui kelayakan model yang akan diterapkan dalam proses pembelajaran. Berdasarkan penilaian dari aspek penilaian kesesuaian isi materi dengan tujuan pembelajaran, dan kebenaran cerita dengan silabus pembelajaran, dari ahli materi diperoleh rerata 4,3. Ini menunjukkan bahwa model pembelajaran yang dikembangkan mempunyai kategori Baik.

Tabel. 2

Hasil Validasi Ahli Model dan Desain Pembelajaran Validasi dilakukan oleh Aay S.Pdi

\begin{tabular}{|c|c|c|c|c|c|c|c|}
\hline \multirow{3}{*}{ No } & & & \multirow{2}{*}{\multicolumn{5}{|c|}{ Skor }} \\
\hline & Aspek & & & & & & \\
\hline & Penilaian & Pernyataan & 1 & 2 & 3 & 4 & 5 \\
\hline \multirow[t]{4}{*}{1} & Komunikasi & Kemudahan bahasa bahan ajar untuk dipahami & & & & $\mathrm{X}$ & \\
\hline & & Logika berfikir & & & $X$ & & \\
\hline & & Kejelasan gambar & & & $X$ & & \\
\hline & & Penggunaan Bahasa & & & & $X$ & \\
\hline
\end{tabular}




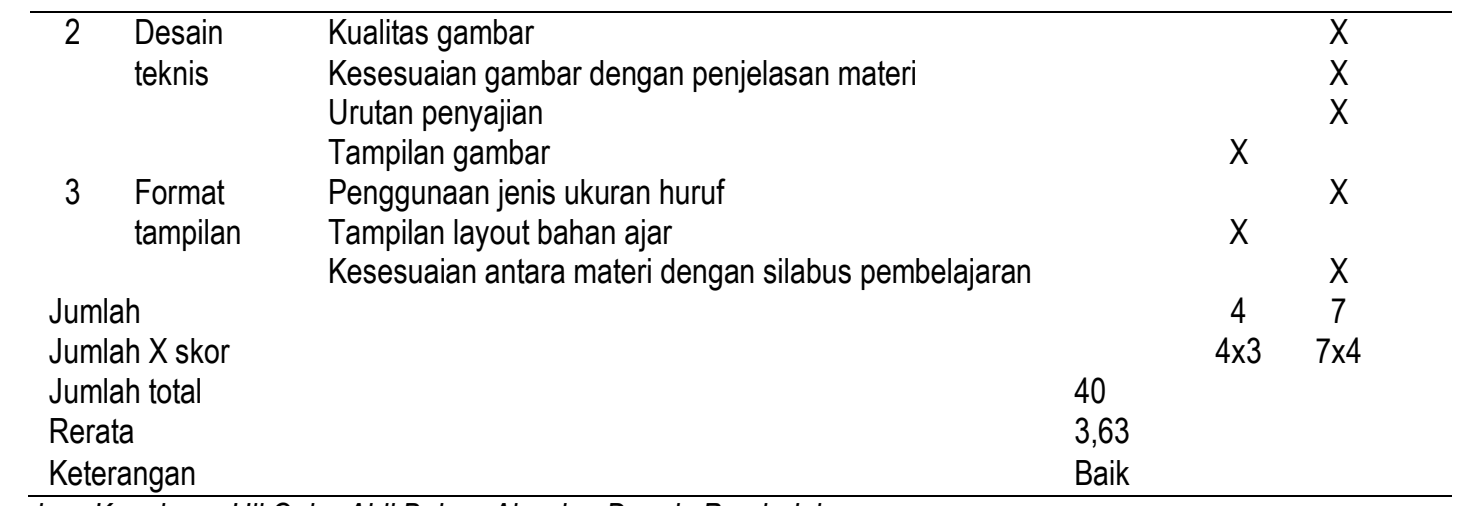

Sumber: Kuesioner Uji Coba Ahli Bahan Ajar dan Desain Pembelajaran

Berdasarkan tabel di atas menunjukan hasil validasi ahli bahan ajar dan desain pembelajaran mempunyai jumlah total nilai 40 dengan rerata 3,63 dan hal ini dinyatakan baik dan layak diterapkan dalam proses pembelajaran.

\section{Hasil Uji Coba Lapangan}

Dari hasil uji coba dilapangan sebesar $80 \%$ pada SD Model Aulady memperoleh prosentasi $75,0 \%$ dan SDN 1 Saguling 72,9\% ini menunjukkan bahwa model pembelajaran Berbasis Buku Cerita Masyarakat Adat Kampung Kuta dalam pengelolaan sumber daya alam yang dikembangkan peneliti adalah cukup baik dan layak digunakan berdasarkan hasil penilaian siswa. Hal ini, dapat dilihat dari hasil yang diperoleh.

\section{Efektifitas Model Pembelajaran IPS Berbasis Buku Cerita Masyarakat Adat Kampung Kuta Dalam Pengelolaan Sumber Daya Alam Untuk Membentuk Karakter Siswa SD Di Kabupaten Ciamis}

Efektifitas pengembangan Model Pembelajaran IPS Berbasis Buku Cerita Masyarakat Adat Kampung Kuta Dalam Pengelolaan Sumber Daya Alam Menurut Menurut Sheu Hsiu-Chih (faizah, 2009) menjelaskan bahwa fungsi gambar dalam cerita setidaknya memiliki dua fungsi, yakni (1) memberikan pemahaman yang menyeluruh/lengkap dan (2) memberikan rangsangan imajinasi.

Selain itu, berdasarkan hasil analisis uji coba di lapangan antara kelas eksperimen dan kelas kontrol terdapat perbedaan hasil belajar yang signifikan, yaitu 2,1\% dan untuk membentuk karakter siswa antara kelas eksperimen dan kontrol juga terdapat pengaruh dari model pembelajaran berbasis buku cerita Masyarakat Adat Kampung Kuta Dalam Pengelolaan Sumber Daya Alam yang dibuktikan dengan hasil perhitungan tersebut.

Berdasarkan hasil penelitian yang telah dilakukan terdapat perbedaan antara siswa yang menggunakan model pembelajaran berbasis buku cerita Masyarakat Adat Kampung Kuta Dalam Pengelolaan Sumber Daya Alam dengan siswa yang tidak menggunakan bahan ajar tersebut.

\section{KESIMPULAN}

Pengembangan dari Model Pembelajaran Berbasis Buku Cerita Masyarakat Adat Kampung Kuta dalam Pembelajaran IPS menunjukkan berdasarkan hasil analisis uji coba di lapangan antara kelas eksperimen dan kelas kontrol terdapat perbedaan hasil belajar yang signifikan, yaitu 2,1\% dan untuk membentuk karakter siswa antara kelas eksperimen dan kontrol juga terdapat pengaruh hal ini dapat di lihat dari hasil observasi yaitu pada SD Model Aulady memperoleh prosentasi $75,0 \%$ dan SDN 1 Saguling $72,9 \%$. 


\section{DAFTAR PUSTAKA}

Aulia, T. O. S., \& Dharmawan, A. H. (2010). Kearifan lokal dalam pengelolaan sumberdaya air di Kampung Kuta. Sodality: Jurnal Transdisiplin Sosiologi, Komunikasi, dan Ekologi Manusia, $4(3), 345-355$.

Davis, G. F., \& Greve, H. R. (1997). Corporate elite networks and governance changes in the 1980s. American journal of sociology, 103(1), 1-37.

Faizah, U. (2009). Keefektifan cerita bergambar untuk pendidikan nilai dan keterampilan berbahasa dalam pembelajaran Bahasa Indonesia. Jurnal Cakrawala Pendidikan, 3(3).

Hidayat. (2011). Pengelolaan sumberdaya alam berbasis kelembagaan lokal. Jurnal Sejarah CITRA LEKHA, Vol. XV, No. 1 Februari 2011. Hal 19-32. Pada tanggal 31 Oktober 2018

Himpunan Perundang-undangan RI tentang Guru dan Dosen. 2006. CV. Nuansa Aulia: Bandung)

Sahlan. (2012). Kearifan lokal masyarakat Tau Taa Wana Bulang dalam mengkonservasi hutan di Provinsi Sulawesi Tengah. MIMBAR HUKUM, Volume 24, Nomor 2, Juni 2012. Hal 187-375. Pada tanggal 31 Oktober 2018

Sondarika, W., \& Ratih, D. (2019). Pembelajaran Sejarah Dalam Mengembangkan Green Behavior Peserta Didik Melalui Nilai-Nilai Kearipan Lokal Hutan Lindung Situ Lengkong Panjalu. Jurnal Wahana Pendidikan, 6(2), 24-41.

Sugiyono. (2009). Metode Penelitian Kuantitatif Kualitatif dan R\&D. Bandung: Alfabeta

Sugiyono. (2012). Metode Penelitian Pendidikan Kuantitatif, Kualitatif, R\&D. Bandung: Alfabeta

Suparmini, Sriadi Setyawati, dan Dyah Respati Suryo Sumunar. (2013). "Pelestarian lingkungan masyarakat Baduy berbasis kearifan local" Humaniora, Vol. 18, No.1, April 2013. Hal 8-22. Pada tanggal 31 Oktober 2018 